\title{
GERAKAN MAHASISWA PADA MASA ORDE LAMA: SUATU PERSPEKTIF HISTORIS
}

\author{
Oleh: Mohammad Maiwan*
}

\begin{abstract}
The student movement in the post-independence as well as the Old Order ups and downs along with the socio-political atmosphere. During the revolutionary period students involved in the struggle for independence. While at the time of Liberal Democracy, student activism changed. At first they are more academic activism alone and free from political interests outside the university. But in the elections of 1955 university and college students have politicized, making it applicable conflict and discord. In the Guided Democracy period (1959-1965)increasing student political activity. Occurs strong government intervention against the university. In addition, the form is also the influence of leftist groups who cause strife and conflicts between student organizations. University of previously fragmented worse. These circumstances occur until 1965 when the Communist Party of Indonesia destroyed.
\end{abstract}

Key Words: Student movement, politics, Old Order era.

\section{Pendahuluan}

Golongan

mahasiswa

merupakan salah satu kekuatan penting dalam proses pembangunan bangsa. Dalam perkembangan sejarah Indonesia moderen kelompok mahasiswa terlibat dalam berbagai pasang surut kehidupan politik. Keterlibatan tersebut sebagai bagian dari wujud kepedulian mereka akan perjalanan bangsa. Meskipun kedudukan mahasiswa tidak dapat disamakan dengan kekuatankekuatan sosial politik formal dalam percaturan politik, namun suara mereka menggambarkan adanya aspirasi dalam masyarakat yang perlu diperhatikan. Karena bagaimanapun suara mahasiswa adalah perpanjangan dari suara masyarakat. Ketidakpekaan pemerintah terhadap aspirasi mahasiswa hampir dapat dipastikan akan mencetuskan konflik yang berujung pada kegaduhan politik.

Secara politis benturan antara mahasiswa dengan pemerintah menjadi cermin tidak berjalannya

\footnotetext{
* Dosen Program Studi Pendidikan Pancasila dan Kewarganegaraan Jurusan Ilmu Sosial Politik, Fakultas Ilmu Sosial Universitas Negeri Jakarta
} 
sebagian fungsi-fungsi dalam pemerintahan secara maksimal. Begitu pula sebaliknya, redamnya gerakan mahasiswa menunjukkan adanya derajad kepuasaan terhadap fungsi-fungsi pemerintahan. Dalam konteks gerakan mahasiswa di Indonesia, relasi antara mahasiswa dan pemerintah dipengaruhi oleh berbagai sebab sehingga menjadikan hubungan diantara keduanya berlangsung secara dinamis sesuai dengan atmosfer sosial politik yang ada. Salah satu episode sejarah yang menunjukan hubungan paling dinamis antara gerakan mahasiswa dan pemerintah adalah yang terjadi pada era pasca kemerdekaan dan Orde Lama. Untuk itu, artikel di bawah ini akan menjelaskan bagaimana dinamika gerakan mahasiswa pada masa tersebut. Faktor-faktor apa yang menyebabkannya, isu-isu apa yang berkembang, serta bagaimana respon negara terhadapnya?

\section{Gerakan Mahasiswa}

Sesudah
Gerakan mahasiswa memasuki tahap baru ketika Indonesia menyatakan diri sebagai negara merdeka. Pada saat itu, keadaan pendidikan, khususnya lembaga pendidikan tinggi belum berlangsung normal (Bachtiar 1968:183; Thomas 1973:40-86). Para mahasiswa di lembaga pendidikan tinggi, di samping belajar juga terlibat secara aktif dalam penentangan bersenjata melawan Belanda. Keterlibatan mahasiswa diwujudkan dalam usaha-usaha yang lebih mendesak untuk mempertahankan kemerdekaan.

Sebagian mahasiswa, bersama-sama pelajar sekolah menengah tergabung ke dalam organisasi Tentara Pelajar (TP), Tentara Republik Indonesia Pelajar (TRIP), Tentara Geni Pelajar (TGP). Sementara sebagian yang lain berjuang bersama kelompok laskar-laskar perjuangan lain berdasarkan hubungan-hubungan keagamaan ataupun golongan. Mereka semua dikenali sebagai, "pelajar pejuang" (Susanto 1985). Sementara sebagian yang lain bergabung ke dalam Corps Mahasiswa (CM) yang kemudian disebarkan ke berbagai front dan markas sebagai kaderkader terdidik untuk mendampingi para komandan, terutama dalam tugas pembinaan teritorial. Tugas mereka adalah ikut aktif menjalankan administrasi pemerintah di daerah-daerah yang masih dikuasai pihak republik. Hal itu wujud terutama pada tahap 
gerilya perang kemerdekaan (Notosusanto 1978: 402-403).

Di luar perjuangan bersenjata, perkembangan dalam dunia mahasiswa diwarnai dengan pembentukan organisasiorganisasi baru serta usaha-usaha untuk mewujudkan persatuan di antara mereka atau pemuda dalam rangka menjayakan revolusi nasional. Dalam kaitan ini, para mahasiswa dan pemuda mengambil langkah penting dengan menyelenggarakan Konggres Pemuda di Yogyakarta tanggal 9-11 November 1945, yang melahirkan organisasi federasi bernama, BKPRI (Badan Kongres Pemuda Republik Indonesia) (Ranuwihardjo 1979: 153). Namun karena adanya dominasi kelompok kiri yang diwakili oleh Pesindo (Pemuda Sosialis Indonesia) (Kahin 1980:201, .339-368) dan wujudnya berbagai perbedaan pandangan politik di dalamnya, BKPRI mengalami perpecahan.

Sebagai gantinya, pada bulan April 1946 diadakan pertemuan mahasiswa seluruh Jawa yang kemudian berhasil mendirikan organisasi baru yaitu, Sarekat Mahasiswa Indonesia (SMI) atau nama lainnya Societas Studisorum Indonesiensis. Kebanyakan anggota SMI berhaluan kiri dan memiliki hubungan erat dengan tokohtokoh komunis. Organisasi ini kemudian pada tanggal 2 Februari 1948 bergabung ke dalam Ikatan Pelajar Indonesia (Soebagijo I.N. 1987:30-31, 65) yang sebagian besar anggotanya adalah pelajarpelajar sekolah menengah dan sebagian kecil mahasiswa. Penggabungan antara dua organisasi tersebut melahirkan Ikatan Pemuda Pelajar Indonesia (IPPI) (Soebagijo I.N. 1987:202-222; Hindley 1966:195-196).

Selanjutnya didirikan organisasiorganisasi mahasiswa yang rapat dengan partai-partai politik yang telah wujud sebelumnya. Pada tanggal 5 Februari 1947 didirikan Himpunan Mahasiswa Islam (HMI) (Tanja1983; Sitompul 1976), sebagai kelanjutan dari didirikannya partai Masyumi 7 November 1945; Perhimpunan Mahasiswa Kristen Indonesia (PMKI) buntut pendirian Parkindo 18 November 1945, dan tanggal 25 Mei 1947 didirikan Perhimpunan Mahasiswa Katolik Republik Indonesia (PMKRI) buntut pendirian Partai Katholik 8 Desember 1945. Corak hubungan organisasi mahasiswa dengan partai politik ini merupakan gejala baru setelah kemerdekaan yang merupakan proses awal yang akan membawa dampak pada politisasi mahasiswa.

Di samping wujud organisasiorganisasi mahasiswa yang berhubung rapat dengan partai-partai politik, muncul pula organisasi-organisasi mahasiswa yang bercorak fungsional, professional dan lokal berdasarkan semangat kedaerahan, dengan skop komunitas yang terbatas dan penekanan yang kentara kepada satu bidang kepakaran (Martha 1985:1999). Namun 
sampai sejauh itu, satu model organisasi yang menghimpun semua kekuatan mahasiswa secara nasional belum ada.

Barulah dalam Konperensi Mahasiswa Indonesia di Malang tanggal 810 Maret 1947 tujuh buah organisasi mahasiswa seperti: HMI, PMKI, PMKRI, PMKH, PMD, PMJ, MMM bersetuju untuk mendirikan Perserikatan Perhimpunan Mahasiswa Indonesia (PPMI) (Martha et al. 1985: 199). Organisasi ini merupakan federasi organisasi ekstra universiter mahasiswa Indonesia. PPMI kemudian berkembang sebagai organisasi mahasiswa yang penting di dalam kancah politik nasional (Anwar 1981:21-25).

Pada peringkat awal, PPMI memiliki hubungan rapat dengan Presiden Sukarno dan Wakil Presiden Mohammad Hatta dan secara langsung dapat memberikan pandangan-pandangannya secara efektif berkenaan dengan perkembangan politik nasional dalam berbagai diskusi bersama. Bahkan pada masa awal tersebut, tokohtokoh PPMI berani memberikan pandangan kepada Presiden Sukarno berkaitan dengan pembentukan kabinet pemerintah (Martha et al. 1985: 200). PPMI bertahan cukup lama dan menjadi bagian dari pasang surut kehidupan politik pada masa Demokrasi Liberal dan Demokrasi Terpimpin.

\section{Gerakan Mahasiswa Pada Masa}

\section{Demokrasi Liberal}

Setelah Perang Kemerdekaan selesai dan Belanda mengakui kedaulatan Indonesia pada bulan Desember 1949, dinamika gerakan mahasiswa memasuki era baru. Kehidupan berjalan semua secara normal, sementara para mahasiswa ataupun pelajar kembali ke universitas maupun sekolah.

Di bidang pendidikan, khususnya lembaga pendidikan tinggi, pemerintah membuka kesempatan yang seluas-luasnya kepada masyarakat untuk mengikuti pendidikan tinggi dengan mendirikan beberapa universitas baru (Thomas 1973;96122; Sanit 1989;20). Sepanjang awal tahun 1950-an, kehidupan universitas berlangsung dalam suasana kegairahan yang tinggi dan kenangan romantik atas revolusi perjuangan yang baru berlalu. Nuansa setelah merdeka memberikan harapan tinggi akan tumbuhnya suasana yang kondusif dalam pengembangan aktifitas ilmiah. Kalangan universitas dapat berkarya secara bebas dan memiliki otonomi yang kuat. Bahkan sebagian mahasiswa terlibat dalam programprogram pembangunan secara langsung (Hardjasoemantri 1983).

Pada tahap ini, universitas telah tumbuh sebagai lembaga yang netral dan bertumpu pada tugas utamanya, yaitu mengembangkan ilmu pengetahuan. Peluang kerja dan karier lulusan mereka setelah 
tamat sangat terbuka luas dalam jabatanjabatan pemerintah seiring dengan wujudnya perluasan birokrasi dalam satu negara baru. Karena itu, tidaklah mengherankan jika generasi mahasiswa pada masa ini setelah tamat dari universitas dengan mudah terserap ke dalam bidang pekerjaan resmi di lembaga-lembaga pemerintah (Fischer 1965:105).

Dalam konteks ini, menjadi penting kenapa pada saat itu tidak wujud suatu gerakan mahasiswa yang bersifat keras yang berupaya menantang pemerintah yang baru wujud. Hal ini berlaku karena struktur yang sedia ada masih cukup luas dan akomodatif untuk menampung tamatan institusi pendidikan tinggi yang masih sedikit (Thomas 1973:92). Di samping itu, sebagian dari mahasiswa pada masa tersebut adalah juga mantan para pejuang yang pernah terlibat dalam perang kemerdekaan, yang notabene juga ikut menyumbangkan berdirinya tatanan yang ada. Mereka memiliki hubungan-hubungan pribadi yang rapat dengan lapisan elite politik nasional yang memerintah yang juga berjuang pada jaman penjajahan dahulu, maupun ketika Perang Kemerdekaan. Lebih dari itu, secara sadar para mahasiswa ini menganggap bahwa belajar juga merupakan kewajiban mulia sebagai bagian mengisi kemerdekaan (Fischer 1965:104).

Pada dasarnya boleh dikatakan bahwa, kurangnya partisipasi politik mahasiswa tersebut disokong oleh realitas, baik subyektif maupun obyektif yang secara mendasar tidak cukup menjadi alasan untuk menentang sistem yang ada. Generasi mahasiswa pada masa ini, tidak berhadapan dengan masalah yang sukar, sebagaimana generasi mahasiswa sesudahnya yang berhadapan dengan masalah kemelut politik, ekonomi maupun sosial sehingga melahirkan tantangan tersendiri. Meskipun mulai muncul kekecewaan dari sebagian kalangan masyarakat terhadap arah tujuan negara baru tersebut, tetapi hampir dipastikan tidak sebesar daripada harapanharapan mereka. Selain itu, mereka sadar bahwa masa pembangunan negara masihpun bermula.

Sementara itu, di lingkungan universitas, dinamika organisasi mahasiswa mengalami perkembangan baru, dalam bentuk didirikannya organisasi-organisasi internal universitas (Martha 1985:270-271). Meskipun di lembaga-lembaga pendidikan tinggi pada saat itu terdapat dua jenis organisasi mahasiswa yang berbeda, yakni, intra dan ekstra universitas, namun keadaan masih tetap normal dan stabil. Aktifitas dan suasana akademik warga kampus masih tetap terjaga dan berjalan dengan baik. Berbagai aktifitas mahasiswa masihpun bersifat akademik semata dan terbebas dari kepentingan-kepentingan politik di luar universitas. Namun secara perlahan seiring dengan berjalannya waktu, serta semakin 
dekatnya waktu Pemilihan Umum 1955, maka kondisi tersebut berubah. Partai-partai politik yang sejak awal menyadari potensi mahasiswa, di tengah langkanya tenagatenaga terdidik berkualitas di masyarakat, dengan serta merta mulai melakukan langkah-langkah mobilisasi politik dengan melibatkan partisipasi warga kampus.

Wujudlah kemudian organisasiorganisasi ekstra mahasiswa yang baru yang menjadi cabang ataupun minimal memiliki hubungan emosional yang rapat dengan partai-partai politik. PNI (Parti Nasional Indonesia) mendirikan GMNI (Gerakan Mahasiswa Nasional Indonesia) pada tahun 1954 (Rocamora 1975:265269), NU (Nahdlatul Ulama) mendirikan IPPNU (Ikatan Pelajar Nahdlatul Ulama), yang kelak di kemudian hari secara khusus mendirikan PMII (Persatuan Mahasiswa Islam Indonesia) (Noer 1987: 93-94). PSI (Parti Sosialis Indonesia) mendirikan GPS (Gerakan Pemuda Sosialis). Seksi Mahasiswa GPS ini di kemudian hari berdiri sendiri dengan nama Gemsos (Gerakan Mahasiswa Sosialis) (Meyrs 1959:112).

Sementara itu, PKI (Partai Komunis Indonesia) menggunakan strategi lain. Partai ini tidak secara langsung mendirikan organisasi mahasiswa, sebagaimana yang ditempuh partai-partai politik lain. PKI baru mendirikan organisasi mahasiswa, yakni CGMI (Consentrasi Gerakan
Mahasiswa Indonesia) tahun 1956 setelah pemilihan umum. CGMI merupakan gabungan dari tiga organisasi mahasiswa lokal, yang telah didirikan sebelumnya tahun 1950, yaitu CMB (Consentrasi Mahasiswa Bandung), CMY (Consentrasi Mahasiswa Yogyakarta) dan GMIB (Gerakan Mahasiswa Indonesia Bogor) ditambah dengan Mahasiswa Progresif dan Persatuan Mahasiswa Demobilisan (Hindley 1966:196-1999; McVey 1990:1923).

Kewujudan organisasi-organisasi mahasiswa ekstra universitas yang baru ini, secara otomatik menambah jumlah barisan organisasi yang sama yang telah disebut di atas. Terlihat dengan jelas bahwa penyusunan kekuatan politik dari universitas ini, mengikuti garis atau kecenderungan ideologi politik, yang menjadi bagian daripada apa yang oleh Clifford Geertz disebut sebagai "politik aliran", di mana kelompok mahasiswa secara mendalam diintegrasikan ke dalam satu kekuatan politik berdasarkan arus kebudayaan utama yang berkembang di dalam masyarakat (Geertz 1976). Kewujudan organisasi-organisasi mahasiswa tumbuh berdasarkan pemisahan ideologi yang tajam yang menjadi dasar perjuangan partai-partai politik. Ben Anderson (1990: 107) secara jitu menggambarkan keadaan ini sebagai berikut: 
"Partai-partai besar masa itu -PKI, PNI, dan NU-- melebarkan sayap kekuatannya bukan saja di kalangan anggota-anggotanya saja, tetapi juga ke dalam segenap organ-organnya yang mencakup anak muda, wanita, pelajar, petani, pekerja, sarjana, dan lainnya...yang saling bersaing dengan sengit memperebutkan pengaruh di segenap lapisan kehidupan masyarakat."

Karena itu, campur tangan partaipartai politik dalam lapisan kehidupan masyarakat, khususnya organisasi mahasiswa terbuka lebar yang ujungujungnya menyeret mahasiswa ke dalam kancah politik praktis. Proses tersebut secara langsung mempengaruhi kehidupan universitas, dengan wujudnya perpecahan dalam kehidupan mahasiswa yang semakin kentara, karena perbedaan-perbedaan asosiasi dan pandangan-pandangan politik. Mulai saat itulah dunia mahasiswa mengalami politisasi yang sesungguhnya.

Dalam Pemilihan Umum 1955, yang merupakan pemilihan umum pertama selepas Indonesia merdeka, universitas menjadi salah satu tempat "pertarungan kekuasaan" dan perebutan pengaruh di antara partai-partai politik, yang dengan segala cara berusaha menarik kalangan universitas. Dalam konteks ini, pola campur tangan politik terhadap kehidupan universitas menampakkan wajah baru (Sanit 1989:21). Para pemimpin politik sadar bahwa, universitas merupakan sumberdaya politik, karena di sana terdapat potensi kepemimpinan dan keterampilan. Upaya kekuatan politik untuk mendapatkannya menyebabkan universitas terjebak ke dalam proses politik (Sanit 1989: 24).

Selepas Pemilihan Umum 1955 yang dimenangi PNI, Masyumi, NU dan PKI yang menghasilkan peta kekuatan politik baru, tidaklah menghentikan politisasi universitas. Suasana politik nasional, yang diliputi konflik-konflik di antara elite politik semakin berterusan, sehingga tidak menghasilkan stabilitas sebagaimana diharapkan dan justru semakin menyeret mahasiswa jauh ke dalam arus politik yang berkembang. Organisasi-organisasi mahasiswa secara permanen kemudian menjadi salah satu benteng dari parti-partai politik di universitas.

Dalam perkembangan tersebut, kelompok mahasiswa menjadi salah satu sasaran penting perluasan pengaruh dalam rangka penguasaan massa oleh kekuatankekuatan politik utama yang sedang bersaing, yaitu Sukarno, Angkatan Darat dan partai-partai politik. Bahkan organisasi federasi mahasiswa ekstra universitas, yakni PPMI juga tidak terlepas dari sasaran politisasi. Untuk menyelamatkan mahasiswa di dalam universitas, sebagian tokoh-tokoh Dewan Mahasiswa Universitas Indonesia tahun 1956 
mempelopori pendirian Majelis Mahasiswa Indonesia (MMI), yang merupakan federasi organisasi mahasiswa intra universitas. Organisasi ini beranggotakan Dewan-Dewan Mahasiswa dan Senat-Senat Mahasiswa seluruh lembaga pendidikan tinggi di Indonesia yang telah ada sebelumnya. Baik PPMI maupun MMI berebut kedudukan untuk mengakui sebagai juru bicara yang mewakili keseluruhan mahasiswa Indonesia (Paget 1970: 161-163). Mulai saat itu muncul dualisme dalam organisasi mahasiswa di Indonesia, yakni antara organisasi ekstra universitas dan intra universitas.

Sementara itu, pada tahun 1957 pihak Angkatan Darat melakukan langkah ofensif dengan mempelopori pendirian BKSPM (Badan Kerjasama Pemuda Militer). Organisasi ini merupakan tempat untuk menghimpun kerjasama di antara institusi-institusi sipil-militer, termasuklah organisasi-organisasi mahasiswa, organisasi pemuda yang mempunyai hubungan dengan partai-partai politik, buruh, petani, wanita, agama dan lain-lain (Lev 1966: 65). Pendirian BKSPM menandai awal peranan pemuda dan mahasiswa dalam arena politik nasional atas namanya sendiri. Ide badan kerjasama ini bertujuan melemahkan peranan partai-partai politik dengan menekankan penyatuan unsur-unsur atas dasar fungsinya. Namun tujuan organisasi ini gagal, sebagian karena keberhasilan partai-partai politik dalam menyesuaikan diri dengan Demokrasi Terpimpin dan sebagian lagi karena langkah-langkah Presiden Sukarno yang ingin menjadi pengimbang kekuatan tentara dan partaipartai politik (Magenda 1985: 136).

\section{Gerakan Mahasiswa Pada Masa}

\section{Demokrasi Terpimpin}

Selanjutnya, pada masa Demokrasi Terpimpin (1959-1965) gerakan mahasiswa telahpun berkembang lebih jauh seiring dengan perkembangan politik yang dinamik dan cepat yang prosesnya sudahpun dimulai pada tahun 1957 (Lev 1966). Kalangan universitas yang sebelum ini, yaitu pada masa Demokrasi Liberal, telah menerima pengaruh dari kekuatankekuatan politik eksternal, kini semakin jauh terlibat ke dalam arus politik. Universitas bukan saja menjadi salah satu benteng perjuangan politik, tetapi juga menjadi arena perebutan pengaruh yang lebih besar yang akan digunakan sebagai alat untuk melakukan bargaining politik. Dalam hal ini, peranan yang lebih besar dalam gerakan mahasiswa tetap dipegang oleh organisasi-organisasi mahasiswa eksternal universitas, yang memiliki hubungan erat dengan partai-partai politik.

Akibatnya, lembaga universitas yang merupakan institusi ilmiah yang pada mulanya independen dan netral dari 
berbagai kepentingan tidak boleh lagi dipertahankan. Salah satu faktor penting yang menyumbang pada meningkatnya gerakan mahasiswa adalah meluasnya partisipasi pendidikan tinggi. Pada masa Demokrasi Terpimpin, terutama pada awal tahun 1960-an pemerintah mendirikan universitas-universitas baru di berbagai daerah, khususnya pada setiap ibukota provinsi (Lev 1966). Bertambahnya jumlah universitas secara otomatis juga menambah jumlah mahasiswa yang meningkat dengan pesat (Fischer 1965:92; Magenda 1985:137; Bachtiar 1968:186, 210). Semakin banyaknya jumlah mahasiswa yang ada di lembaga pendidikan tinggi tersebut, pada prinsipnya telah menggeser persepsi umum akan kedudukan mereka sebagai satu "entitas sosial" yang pada asalnya bersifat ekslusif menjadi lebih massal dan egaliter. Para mahasiswa harus berhadapan dengan realitas bahwa mereka adalah sama dengan kelompok-kelompok sosial masyarakat lainnya.

Apatah lagi realitas menunjukkan bahwa kedudukan mahasiswa setelah tamat belum dapat menjamin masa depan yang cerah, mengingat banyaknya lulusan lembaga pendidikan tinggi tidak cukup ditampung dalam sistem politik yang ada, telah mulai menimbulkan "pengangguran terdidik" serta bentuk-bentuk kekecewaan dan frustasi di kalangan mereka. Meskipun terdapat perluasan dalam birokrasi pemerintahan, namun besarnya jumlah lulusan tidaklah sepadan dengan bidang yang tersedia. Dalam keadaan ekonomi negara yang kocar-kacir serta belum berkembangnya sektor-sektor swasta yang kuat dan meluas, maka tumpuan bekerja pada jabatan-jabatan dalam pemerintah merupakan satu-satunya harapan bagi mereka yang berpendidikan tinggi.

Selain itu, meningkatnya aktifisme mahasiswa sebagian besar juga dipengaruhi oleh perkembangan politik nasional, yang diwarnai usaha-usaha Presiden Sukarno untuk mempromosikan satu ideologi nasional dengan menekankan pada tema-tema "kebanggaan nasional", "persatuan bangsa", "revolusi belum selesai" dan lain-lain dengan harapan dapat memelihara keseimbangan di antara faksifaksi politik yang berbeda-beda. Pada tahun 1959 Sukarno mengemukakan gagasannya tentang Manipol-USDEK yang merupakan penjabaran lebih lanjut dari ide beliau tentang revolusi, politik dan ideologi negara (Feith 1968:594-595; Feith 1967:367-368).

Pada tingkat inilah kemudian pemerintah menjadikan universitas dan mahasiswa menjadi salah satu sasaran indoktrinasi politik (Thomas 1973:181182). Meskipun ideologi Manipol-USDEK ini menarik bagi sebagian mahasiswa, namun indoktrinasi itu, untuk sebagian, 
disambut dengan sikap permusuhan, sinisme dan sebelah mata, yang hanya akan mengancam kebebasan (Feith 1967: 370). Respon sebagian mahasiswa terhadap ideide politik pemerintah merentang antara penentangan terselubung dan kemauan umum yang tidak dapat ditolak. Namun untuk sebagian yang lain, justru disambut secara antusias, menjadi tanda kesetiaan yang meluap-luap. Para mahasiswa kiri segera menanggapi indoktrinasi ini sebagai kesempatan untuk mengambil inisiatif dalam memimpin sekaligus mendominasi wacana dan gerakan politik di universitasuniversitas serta konstelasi politik nasional.

\section{Dalam}

perkembangan berikutnya pemerintah juga menggerakkan mahasiswa untuk kepentingan politik, ketika pada tanggal 19 Desember 1961 Presiden Sukarno menyampaikan maklumat Trikora (Tri Komando Rakyat), yang berisikan seruan untuk merebut Irian Barat. Inisiatif tersebut disambut mahasiswa yang kemudian bersama pihak Angkatan Darat mewujudkan latihan-latihan ketentaraan (Martha 1985:319). Langkah ini sekaligus ditempuh untuk membendung "Nasakomisasi" dan pengaruh kelompok kiri di universitas. Karena itu, para mahasiswa kiri dengan keras menuduh tentara telah melakukan "militerisasi kampus".

Namun demikian, selepas itu, situasi nasional tidaklah bertambah baik. Kehidupan ekonomi masyarakat secara umum semakin merosot. Politik Indonesia kemudian bergeser ke kiri, sehingga lebih mendekatkannya dengan blok komunis. Dalam politik luar negeri, Indonesia membentuk poros Jakarta-Phnom PenhHanoi-Peking-Pyongyang, sehingga harus berhadapan dengan blok Barat. Puncak dari permasalahan ini adalah keluarnya Indonesia dari organisasi PBB (Perserikatan Bangsa-Bangsa) pada awal tahun 1965, yang menyebabkan Indonesia semakin terkucil dari pergaulan masyarakat internasional (Leifer 1983: 103-105).

Dengan bersandarkan kepada ajaran-ajaran Presiden Sukarno faksi kiri berusaha membenarkan langkah-langkah politiknya. Serangan-serangan PKI semakin gencar diarahkan kepada kekuatankekuatan yang dianggap potensial sebagai lawan politik. Melalui organisasi-organisasi di bawahnya, PKI, berusaha meningkatkan 
pertentangan-pertentangan dalam masyarakat, di samping secara berterusan melakukan penyusupan secara sistematik ke dalam pelbagai organisasi lain sebagaimana sebelumnya (Legge 2001:387-388).

Sementara itu, di lingkungan organisasi mahasiswa, kelompokkelompok organisasi mahasiswa kiri yang dipelopori oleh GMNI, CGMI, Germindo (Gerakan Mahasiswa Indonesia) dan Perhimi (Perhimpunan Mahasiswa Indonesia) (Maxwell 2001:140) berusaha untuk meminggirkan lawan-lawan politiknya dengan berbagai cara, sehingga muncul pertentangan di antara mahasiswa yang pro dan antikomunis. Usaha-usaha untuk mendominasi kehidupan universitas dilakukan bukan saja dengan melumpuhkan organisasi-organisasi ekstra universitas saja, tetapi juga menguasai organisasi-organisasi intra universitas, seperti Dewan-Dewan Mahasiswa di berbagai universitas, serta menyingkirkan para dosen yang dianggap sebagai musuh politik.

Akibatnya, universitas berubah menjadi semacam ajang "gimnastikrevolusioner", tempat untuk praktek "pertentangan kelas" seperti dosen versus mahasiswa, ataupun screening mahasiswa dan retooling atau pelucutan jabatan terhadap dosen yang tidak disukai. Dalam konteks ini, mahasiswa telahpun muncul sebagai faktor politik di dalam universitas, bahkan diakui sebagai kekuatan sosial politik yang boleh mempengaruhi berbagai keputusan (Moechtar 1998:44-46).

Serangan-serangan mahasiswa kiri ini juga disertai dengan usaha-usaha mereka yang meningkat dalam menguasai organisasi eksternal maupun internal universitas. Sasaran mereka yang pertama adalah PPMI yang sebelumnya telah berhasil disusupi (Martha 1985:304). Selain menguasai organisasi eksternal universitas, mahasiswa-mahasiswa progresif revolusioner kiri juga berusaha keras menguasai perhimpunan organisasi internal universitas, yaitu MMI. Puncak dari kejadian tersebut adalah dalam Kongres MMI yang ke IV April 1964 di Malino Sulawesi Selatan, di mana kelompok mahasiswa kiri pimpinan CGMI berhasil memenangi pertarungan dengan menguasai MMI, yang kemudian mendapatkan tantangan dari Dewan Mahasiswa Universitas Indonesia (UI), Dewan Mahasiswa Institut Teknologi Bandung (ITB) dan Dewan Mahasiswa Universitas Padjajaran (Unpad) (Martha 1985:304).

Karena itu, segera setelah Konggres MMI ke IV di Malino selesai, terjadi pergulatan pada Dewan-Dewan Mahasiswa di seluruh lembaga pendidikan tinggi Indonesia. Wujud usaha-usaha serius 
mahasiswa kiri untuk menjatuhkan ketuaketua Dewan Mahasiswa di lembaga pendidikan tinggi. Beberapa universitas utama menjadi sasaran penting yang secara berterusan berusaha untuk dikuasai. Meskipun tidak semua tujuan dari mahasiswa-mahasiswa progresif revolusioner kiri tersebut berhasil, namun realitanya tindakan mereka menimbulkan "efek psikologikal" yang luar biasa terhadap kelompok-kelompok mahasiswa yang berseberangan, sehingga menyebabkan mereka bersikap defensif.

Bahkan, pada tahap tertentu, keberhasilan tersebut semakin memperkuat keyakinan kelompok mahasiswa kiri untuk meminggirkan lawan-lawan mereka. Salah satu organisasi mahasiswa terpenting yang dijadikan sasaran adalah HMI. Para mahasiswa kiri menuntut agar HMI dibubarkan (Sitompul 1976:43). Namun usaha tersebut gagal, karena tuntutan pembubaran HMI memperoleh tantangan yang luas dari kelompok-kelompok antikomunis.

Organisasi-organisasi mahasiswa anti-PKI seperti: PMKRI, PMII, GMKI, dan lain-lain dengan keras membela HMI. Mereka melihat bahwa, hancurnya HMI justru akan memperlemah barisan sipil yang berada di universitasuniversitas. Karena itu, berbagai usaha untuk menyelamatkan HMI dilakukan dan berhasil. Presiden Sukarno menyatakan bahwa organisasi tersebut boleh terus wujud, seraya mengingatkan agar organisasi HMI tidak menjadi sarang kontra-revolusi dan jiwa kekolotan (Rosihan Anwar 1981: 468). Meskipun demikian, di pihak lain CGMI bersama organisasi-organisasi kiri lainnya secara terus menerus mencari jalan dan akhirnya berhasil memperalat PPMI, sebagai wadah federasi organisasi mahasiswa, yang kemudian menggantung keanggotaan HMI dari PPMI, pada tanggal 21 Oktober 1964 (Sitompul 1976: 50).

Di lingkungan mahasiswa serangan kelompok kiri, bukan saja berhenti kepada HMI saja, tetapi diperluaskan kepada berbagai organisasi mahasiswa nonkomunis lainnya. Bahkan mereka merancang untuk menyerang organisasiorganisasi mahasiswa yang lebih kecil dan netral, yang tidak memiliki hubungan dengan partai politik, termasuklah di dalamnya organisasi-organisasi mahasiswa lokal seperti: IMADA, IMABA, PMB dan lain-lain.

Meskipun, untuk sebagian, usaha kelompok revolusioner progresif kiri gagal mencapai tujuannya dengan baik, namun pada aspek lain mereka justru memperoleh beberapa keberhasilan penting. Mereka misalnya, berhasil mendesak agar Manifesto Kebudayaan dilarang, media pers yang pro BPS (Badan Penyokong Sukarnoisme) dan antikomunis dilarang, serta partai-partai politik --seperti Partai 
Murba pada 21 September 1965-- yang memungkinkan Nasakomisasi dapat terus berlangsung dan PKI memiliki posisi yang kuat, juga dilarang. Sepanjang masa Demokrasi Terpimpin kelompok kiri telah berkembang pesat dan untuk sebagian berhasil memberikan pengaruh penting atas arena politik nasional. Keadaan tersebut berlangsung sampai dengan tercetusnya peristiwa $30 \mathrm{~S}$ PKI tahun 1965 di mana PKI dituduh sebagai pelaku percobaan kudeta yang gagal. Organisasi ini beserta seluruh insitusi-institusi massa di dalamnya kemudian menjadi sasaran kemarahan kelompok antikomunis, termasuk mahasiswa.

\section{Kesimpulan}

Dari uraian di atas dapat dikemukakan kesimpulan bahwa gerakan mahasiswa pada masa pasca kemerdekaan serta Orde Lama mengalami pasang surut seiring dengan suasana sosial politik yang ada. Gerakan mereka memasuki dimensi baru ketika Indonesia memproklamasikan kemerdekaan tahun 1945. Banyak di antara mahasiswa yang bergabung pada sejumlah organisasi atau lasykar bersenjata dan dikenali sebagai "pelajar pejuang". Sementara pada masa Demokrasi Liberal, corak aktifisme mahasiswa berubah. Seiring dengan dinamika politik kebangsaan yang meningkat pesat, khususnya menjelang Pemilihan Umum 1955, mahasiswa mengalami politisasi yang tinggi, terseret dalam arus kepentingan partai-partai politik yang menerobos memasuki dunia universitas. Universitas kemudian menjadi salah satu tempat "pergulatan kekuasaan" dan perebutan pengaruh kekuatan eksternal.

Bahkan, pada masa Demokrasi Terpimpin (1959-1965) gerakan mahasiswa telahpun berkembang lebih jauh sejajar dengan perkembangan politik nasional. Kehidupan universitas yang sebelumnya telah terpecah-belah, semakin parah. Konflik di antara kelompok dan organisasi mahasiswa, khususnya dengan mahasiswa "kiri" meningkat. Pada tahap ini, kalangan kiri, dengan berbagai cara, berusaha mendominasi kehidupan universitas dan mahasiswa. Akan tetapi, keadaan tersebut berakhir dengan antiklimaks ketika pada tahun 1965 pihak Komunis dituduh terlibat dalam aksi kudeta yang gagal, sehingga seluruh sayap organisasi kiri, termasuklah organisasi mahasiswanya dihancurkan.

\section{DAFTAR RUJUKAN}

Amstutz, J.B. 1958. The Indonesian youth movement 1908-1955. Tesis Ph.D. Fletcher School of Law and Diplomacy, Tufts University, Medford.

Anwar, R. 1981. Sebelum prahara: pergolakan politik Indonesia 19611965. Jakarta: Sinar Harapan. 
Bachtiar, H.W. 1968. Indonesia. Dlm. Emmerson, Donald K. (pnyt.). Students and politics in developing nations, hlm. 180-214. New York: Frederick A. Praeger, Inc., Publishers.

Coleman, J.S. (pnyt.). 1965. Education and political development. Princeton New Jersey: Princeton University Press.

Dahm, B. 1988. Sejarah Indonesia abad kedua puluh. Terj. Abd. Aziz Hitam \& Wan Azaham Wan Mohamad. Kuala Lumpur: Dewan Bahasa dan Pustaka.

Diah, B.M. 1981. Angkatan Baru '45. Jakarta: Masa Merdeka.

Feith, H. 1967. Dynamics of guided democracy. Dlm. McVey, Ruth T. (pnyt.). Indonesia, hlm. 317-382. New Haven: Human Relations Area Files.

Feith, H. 1968. The decline of constitutional democracy in Indonesia. Ithaca, New York: Cornell University Press.

Fischer, J. 1965. Indonesia. Dlm. James S. Coleman (pnyt.). Education and political development, hlm. 92-122. Princeton, New Jersey: Pinceton University Press.

Geertz, C. 1976. The religion of Java. Chicago: University of Chicago Press.

Hardjasoemantri, K. 1983. Peranan proyek PTM dalam pengembangan pendidikan. Jakarta: Balai Pustaka.

Hindley, D. 1966. The communist party of Indonesia 1951-1963. Berkeley: University of California Press.
Kahin, G.M.T. 1980. Nasionalisme dan revolusi di Indonesia. Terj. Ismail bin Muhammad \& Zaharom bin Abdul Rashid. Kuala Lumpur: Dewan Bahasa dan Pustaka.

Legge, J.D. 2001. Sukarno, biografi politik. Terj. Tim PSH. Jakarta: Sinar Harapan.

Leifer, M. 1983. Indonesia's foreign policy. London: George Allen \& Unwin.

Lev, D.S. 1966. The transition to guided democracy: Indonesian politics 1957-1959. Monograph series. Ithaca, New York: Modern Indonesian Project, Southeast Asia Program Department of Asian Studies Cornell University.

Magenda, B.D. 1985. Gerakan mahasiswa dan hubungannya dengan sistem politik. Dlm. Farchan Bulkin (pnyt.). Analisa kekuatan politik Indonesia, hlm. 129-148. Jakarta: LP3ES.

Martha, A.G., Wibisono, C. \& Anwar, Y. 1985. Pemuda Indonesia dalam dimensi sejarah perjuangan bangsa. Jakarta: Kurnia Esa.

Maxwell, J. 2001. Soe Hok Gie: pergulatan intelektual muda melawan tirani. Terj. Tri Wibowo Budi Santoso. Jakarta: Pustaka Utama Grafiti.

McVey, R.T. 1990. Teaching modernity: the PKI as an educational institution. Indonesia 50(Oktober):5-28.

Moechtar, H. 1998. Mereka dari Bandung: pergerakan mahasiswa Bandung 1960-1967. Bandung: Alumni.

Myers, R.J. 1959. The development of the Indonesian socialist party. Tesis $\mathrm{Ph} . \mathrm{D}$. University of Chicago. 
Noer, D. 1987. Partai Islam di pentas nasional 1945-1965. Jakarta: Pustaka Utama Grafiti.

Padmodiwiryo, S. 1995. Memoar Hario Kecik: autobiografi seorang mahasiswa prajurit. Jakarta: Yayasan Obor Indonesia.

Paget, R. 1970. Youth and the wane of Sukarno's government. Tesis Ph.D. Cornell University, Ithaca.

Rocamora, J.E. 1975. Nationalism in search of ideology: the Indonesian nationalist party 1946-1965. Quezon City: University of the Philippines.

Sanit, A. 1989. Mahasiswa, kekuasaan dan bangsa: refleksi dan gagasan alternatif. Jakarta: Lingkaran Studi Indonesia dan Yayasan LBH Indonesia.

Sitompul, A. 1976. Sejarah perjuangan Himpunan Mahasiswa Islam (19471975). Surabaya: Bina Ilmu.
Soebagijo, I.N. (pnys.). 1987. Perjuangan pelajar IPI-IPPI. Jakarta: Balai Pustaka.

Susanto, S. 1985. Perjuangan tentara pelajar dalam perang kemerdekaan Indonesia. Yogyakarta: Gadjah Mada University Press.

Tanja, V. 1982. Himpunan mahasiswa Islam. Jakarta: Sinar Harapan.

Thomas, R.M. 1969. Effects of Indonesian population growth on educational development, 1940-1968. Asian Survey. Vol. IX, No. 7(July): 498514.

Thomas, R.M. 1973. A chronicle of Indonesian higher education. Singapore: Chopmen Enterprises. 